\title{
NOTES
}

\section{HOLOGRAPH MANUSCRIPT OF "THOU VAST RONDURE" COMES TO LIGHT ON LONG ISLAND}

On 17 December 1868 Whitman wrote John Morley, the editor of Fortnightly Review, to offer him a poem on which he set a price of " 4 pounds $-\$ 20$-in gold-and four copies of the number in which it is printed, sent me by mail." ${ }^{1}$ Whitman does not give the title of the poem, nor does Morley's response on 5 January 1869, when he explains that he cannot find room for the poem before April. "If that be not too late for you," he continues, "and if you can make suitable arrangements for a publisher in the United States so as not to interfere with us in point of time, I shall be very glad."2 Whitman agreed to the April date, then wrote James T. Fields, editor of Atlantic Monthly, and offered him the poem. ${ }^{3}$ Explaining his agreement with Morley, Whitman gave Fields the option of refusing a piece "which is to appear elsewhere." The price to Fields was the same as to Morley, and from this letter we learn the name of the poem being offered, "Thou vast Rondure swimming in Space."5

Whitman gave Horace Traubel the letter from Morley as evidence of a more favorable reaction from an editor than others he had received, and Traubel quotes Whitman as saying:

I sometimes growl a little about the editors but after all they are a good lot-they do the best they can. Besides, I am an incongruity to most of them-I make the sort of noise they don't like-I upset some things they do like: why should I expect to be received. . . . I used to worry over it, just a little-resent it too, just a little: I am past that now. ${ }^{6}$

This was just a few days short of Walt's seventieth birthday, and as was always the case, when his birth date arrived he fell into a mood of self-evaluation. He concludes on a positive note, however: "The fact is, a few people are now listening to me-just a few: I am getting a foothold: I ought to be, I am, satisfied."

Despite the upbeat note of conclusion one wonders if the poet did not resent "just a little" that neither Atlantic Monthly nor Fortnightly Review ever printed "Thou Vast Rondure." In fact, although it appeared in slightly altered form as section five of the 1871 "Passage to India," the poem was never published independently. Evidence now exists, however, that the original version was once printed by Rome Brothers for Whitman according to a holograph manuscript he sent them. It is this manuscript that has come to light on Long Island, bearing every mark of authenticity, including a supportable provenance. ${ }^{8}$

The paper on which the poem is written is approximately 20 inches long and 10 inches wide, with lightly ruled blue lines. It is mounted on gray pasteboard that extends about 2 inches beyond each of the paper's four sides. Distinct traces of what has been determined to be a wheat paste adhere to the right, left, and bottom borders. On the top border, written in pencil, is the following: "Tom-set up same style as before \& send me a proof by middle of the week-W." On the bottom border there is faint evidence of pencil markings that have been obliterated by paste, leaving only what appears to be the letter "c" visible. The poem, written in black ink, reads as follows: 
Thou Vast Rondure Swimming in Space

by Walt Whitman

\section{1}

Thou vast Rondure, swimming in space!

Cover'd all over with visible power \& beauty,

Alternate light \& day, and the teeming, spiritual darkness!

Unspeakable, high procession of sun and moon, and countless stars, above!

Below, the manifold grass and waters, animals, mountains, trees!

With ever inscrutable purpose-some hidden prophetic intentions

Now, first, it seems, my thought begins to span thee.

Adam and Eve appear, and their myriad projeny after them,

Wandering, yearning, curious - full of aspirations

Full of questionings, baffled, formless, feverishwith never-happy hearts;

With that sad, incessant refrain, Wherefore, unsatisfied, Soul? and, Whither, 0 mocking Life?

Ah, who shall soothe these feverish children

Who speak the secret of impassive Earth?

Who bind it to us? What is this separate Nature, so unnatural?

What is the Earth, to our affections? (unloving Earth, without a throb to answer ours;

Cold Earth, the place of graves.)

But haply, finally, shall come the Poet, worthy that name;

The true Son of God shall come, singing his songs;

Then all these hearts, as of fretted children shall be sooth'd

All affection shall be fully responded to-the secret shall be told;

All these separations and gaps shall be taken up and hooked and link'd together;

The Earth-aye, this cold, impassive voiceless earth, shall be completely justified.

Trinitas divine shall gloriously accomplish and compact itself; 
Nature and restless Man shall be dis-

join'd and diffused no more;

The true Son of God shall absolutely

fuse them.

The penultimate line of stanza one, beginning "With ever inscrutable purpose" is squeezed between the lines above and below, and the " $h$ " in "prophetic" has been added with a caret. The hyphen in "never-happy hearts" of stanza two is doubled, as was Whitman's custom, and three short lines under the capitalized " $S$ " and " $G$ " in "Son of God" in stanza three are clearly visible indications to the printer, like those in other manuscripts Whitman sent to his printers. The handwriting is close to that in the facsimile of the 1860 "Blue Book," though more carefully written, since this is not a working copy but a finished poem.

Many Whitman scholars will no doubt recognize this version from The Gathering of the Forces; Editorials, Essays, Literary and Dramatic Reviews and Other Material Written by Walt Whitman as Editor of the Brooklyn Daily Eagle in 1846 and 47,2 vols. Bound into volume one at page 260 is a foldout sheet bearing a facsimile of "Thou Vast Rondure." Below the poem is this note: "Facsimile of manuscript with instructions to 'Tom' Rome one of the Rome brothers, printers, in whose office in Brooklyn the first edition of Leaves of Grass was printed. Published through courtesy of Mrs. St. Clair McKelway of Brooklyn."9 The facsimile duplicates the manuscript in every way, except that the three-line underscoring of the "S" and " $\mathrm{G}$ " and the double hyphen do not show clearly, nor do the blue lines of the paper. The duplication extends even to the wide space that occurs between lines four and five of stanza two, and an ink-closed bowl in the letter " $\mathrm{d}$ " in "Cover'd" in line two of stanza one.

A typed note inserted in the Oscar Lion Collection manuscript of "Passage to India" provides further amplification. The sheet of notes was typed in 1920 by Emory Holloway, who cites a letter in With Walt Whitman in Camden, 1:216, saying the poem was to appear in the Fortnightly Review, and perhaps also in Atlantic Monthly. Holloway also notes that section five of "Passage to India," in slightly altered form, was printed in facsimile by the Brooklyn Daily Eagle, 26 October 1911 with the following comment:

Here is presented a facsimile of one of the literary treasures of Mrs. St. Clair McKelway, who has permitted the Eagle to photograph it. It is a copy of the original manuscript of one of Walt Whitman's early poems, "Thou Vast Rondure Swimming in Space" ... The "Tom" addressed as to the proof at the top, in the handwriting of Whitman, in pencil, was Thomas Rome, an intimate friend and devout admirer of the poet long before he was recognized by the world. Mr. Rome was a printer, conducting with his brother, a printing office in Fulton street, in Brooklyn. ... It was a labor of love for "Tom" Rome to set up the offerings of the poet.

In the course of time Mr. Rome had accumulated a number of the original manuscripts of Whitman, which, after the poet had become famous, he sold to Benjamin, the autograph dealer in Manhattan. Of those he retained the one, a copy of which is below, he gave before his death, to Ulysses S. Scollay, a young man, who was the son of an intimate friend. Mr. Scollay, after holding it a while, gave it to Mrs. McKelway, who cherishes a document so well authenticated, the value of which can hardly be underestimated [sic]. ${ }^{10}$

Holloway's notes provide much information helpful in establishing a provenance for the manuscript of "Thou Vast Rondure." To them can be added "Whitman Manuscripts in Possession of T. H. Rome, 513 Lafayette Avenue, Brooklyn, N.Y.," 
a list that appears in Whitman's Manuscripts, Leaves of Grass (1860), A Parallel Text. This list is a leaf "printed on one side of the paper, found among the material pertaining to Whitman in a bound volume containing an early manuscript of 'Passage to India' deposited in the New York Public Library by Mr. Oscar Lion in 1954. It appears to be a list offering the manuscript for sale...."11 Two items are listed without numbers; the final item is "Thou Vast Rondure Swimming in Space" with "(U. S. Scollay)" written beneath. From this it can be concluded that Tom Rome did in fact give the manuscript of this poem to Ulysses S. Scollay.

That Scollay then gave it to Mrs. St. Clair McKelway may be surmised from her calling card which accompanied the manuscript at the time of its discovery on Long Island in 1986. Under the printed name there had been added in heavy black ink the words "and N[?]ora." Above the inscribed name and in the same hand was written a short sentence which is not perfectly clear: "To HanS of The 'Eagle Family."”

Identification of Mrs. McKelway helps to set the picture in focus and makes her possession of the poem more plausible. Virginia McKelway (née Thompson) was the widow of St. Clair McKelway, a newspaper man who joined the staff of the Brooklyn Eagle in 1868 and moved up the editorial ladder, becoming associate editor in 1883 and editor-in-chief in 1885. He died in 1915. The "Nora" whose name is written on the card might conceivably have been a step-daughter of Mrs. McKelway since the first wife of St. Clair McKelway was Eleanor Hutchinson who died in 1884, four years before his marriage to Virginia Brooks Thompson. As to the penned note, it is quite possible that a true reading is "To Hen S of The 'Eagle Family." This would suggest William Henry Sutton, the fifteen-year-old printer's devil who was a special favorite of Whitman's when he was editing the Eagle. Whitman called him "Hen," and since Holloway tells us that the office force of the Eagle "consisted of only five or six persons including the proprietor, Isaac Van Anden, and the devil, Will Sutton," it is likely that they thought of themselves as a "Family."12 Sutton was still alive in 1920, so the gift of a Whitman manuscript from Mrs. McKelway and "Nora" could have been made to him at some time after the facsimile appeared in the October 1911 Daily Eagle.

When Whitman offered "Thou Vast Rondure" to Morley and to Fields he retained the right to publish the poem in a future book. The book he was planning began with the 1871 "Passage to India" and was still on his mind at the time of the 1876 "Preface" where he speaks of a further volume that would sing "the unseen Soul." Clearly "Passage to India" transcends the material achievements which serve as the poem's occasion, moving quickly to an emphasis on the impelling spirit working out, through such human accomplishments, a great, all-encompassing plan. Because the poem is one of Whitman's more tightly structured, with each of the parts organically fitted to the whole, it is dangerous to attempt a deconstruction. Yet if one were to ask where the central point of the poem lies, what the focal point at which all the lines of its construct intersect, one would have to say it is at that portion that begins " $O$ vast Rondure, swimming in space. ..." 


\section{NOTES}

1 Whitman, The Correspondence, ed. Edwin Haviland Miller (New York: New York University Press, 1961), 2:75.

2 Horace Traubel, With Walt Whitman in Camden (New York: Rowman and Littlefield, 1961), 1:216.

3 Traubel, 216, 217.

4 Traubel, 217.

5 Traubel, 216. The " $\mathrm{s}$ " in swimming is capitalized in the manuscript.

6 Traubel, 217.

7 Traubel, 217.

8 The manuscript poem remains in the hands of the present owner to whom I am grateful for the photographic reproduction.

9 See The Gathering of the Forces, ed. Cleveland Rodgers and John Black (New York: G. P. Putnam, 1920).

10 Emory Holloway, "Notes on 'Passage to India' including 'Thou Vast Rondure,"' Typescript, 20 December 1920. Rare Books and Manuscript Division, The New York Public Library, Astor, Lenox and Tilden Foundations.

11 Fredson Bowers, Whitman's Manuscripts, Leaves of Grass (1860), A Parallel Text (University of Chicago Press, 1955), xix, xx.

12 Emory Holloway, Whitman, An Interpretation in Narrative (New York: Alfred A. Knopf, 1926), 5.

\section{TWO CITATIONS: AN EARLY WHITMAN ARTICLE AND AN EARLY REPRINTING OF "DEATH IN THE SCHOOL-ROOM"}

As Scott Giantvalley and all bibliographers know, completeness is virtually impossible: he himself, in the Walt Whitman Quarterly Review, 4 (Summer 1986): 2440, adds 120 items to his massive Walt Whitman, 1838-1939: A Reference Guide(Boston: G. K. Hall, 1981). An additional article is:

Anon. "Our Boston Literary Letter: Whittier, Whitman, Emma Lazarus." The Daily Springfield Republican, 15 January 1889, pp. 2-3.

The author of this unsigned review-essay begins: "The definitive edition of Whittier's works, both verse and prose, in seven volumes, four of which are in verse, has been appealing to me for some weeks to write its eulogy and critique; and now has come as a holiday gift from the good gray poet himself the more pathetic definitive edition, in one volume of Walt Whitman's verse and prose, - his 'Complete Poems and Prose,' 1855-1888, 'Authenticated and Personal Book (handled by W. W.),' in which the stout-hearted, but feeble-bodied, old man says his long farewell to his readers." After a full column and a half comparison of Whittier and Whitman, the reviewer-essayist devotes a long paragraph to Emma Lazarus, in 